\title{
IWONA BRANC
}

Biblioteka Naukowa PAU i PAN w Krakowie

\section{LISTY ZOFII STRYJEŃSKIEJ (1891-1976) \\ DO ZOFII I ZDZISŁAWA JACHIMECKICH W ZBIORACH BIBLIOTEKI NAUKOWEJ PAU I PAN W KRAKOWIE}

Słowa kluczowe: Zofia Stryjeńska, Zofia Jachimecka, Zdzisław Jachimecki, muzykologia XX w., malarstwo XX w., teatr polski XX w., korespondencja XX w., Kraków (Polska) życie intelektualne - XX w.

W ostatnich latach obserwujemy rosnące zainteresowanie Zofią Stryjeńską artystką ambitną, poszukującą i wierną swoim ideom, a równocześnie osobą o splątanych losach i bogatym życiorysie. W 1936 roku pisała:

Teraz dzieci moje biedne są dla mnie nieosiągalne [...] między nimi a mną stoi okropny wampir-blejtram z naciągniętym płótnem i obmierzłe szczotki zwane pędzlami, którymi posługuję się w celach zarobkowych w sposób poniżający miano Artysty ${ }^{1}$.

Tęsknota za dziećmi i rodzinnym życiem, a jednocześnie brak możliwości realizowania się w roli matki, odbiły piętno w późniejszym życiu na jej psychice.

Obecnie artystkę można uznać za symbol wyzwolenia i niezależności kobiet, dopiero niemal pół wieku po śmierci została zauważona i doceniona. Zajmuje zasłużone miejsce $\mathrm{w}$ gronie kobiet, które musiały wykonać o wiele więcej pracy niż mężczyźni, zmagając się z przeciwnościami losu, brakiem odpowiedniej edukacji i utartymi schematami. W XXI wieku Stryjeńska posiada swoją stronę na Facebooku, założoną przez Wydawnictwo Czarne oraz audiobooka w projekcie Jej historia. Portrety audio - Zofia Stryjeńska, przedstawiającym losy niezwykłych Polek $^{2}$. Odgrywany jest również monodram na podstawie życiorysu artystki pt. Let's dance, Zofia! w reżyserii Joanny Lewickiej.

Dzięki bezpośredniości i współczesności przywołanej korespondencji jej autorka wydaje się kobietą ponadczasową. Edycja listów jest pretekstem do wspomnienia zjawiskowej Zofii Stryjeńskiej, niepowtarzalnej artystki, na nowo odkrywanej

1 Z. Stryjeńska, Chleb prawie że powszedni. Kronika jednego życia, oprac. M. Budzińska i A. Kuźniak, Wołowiec 2016, s. 153.

2 W. Wi er zchow s ka, Jej historia. Portret audio - Zofia Stryjeńska, https://storytel.com/pl/ pl/books/773371-Jej-historia-Portret-audio-S1E4-Zofia-Stryjenska (dostęp: 20.03.2019). 
we współczesnej sztuce. Jest także przypomnieniem postaci Zofii i Zdzisława Jachimeckich, którzy przyczynili się do rozwoju intelektualnego i kulturalnego życia Krakowa, zostawiając po sobie bogaty dorobek naukowy - niestety pozostających w cieniu wspomnien.

Listy Zofii Stryjeńskiej do Zofii i Zdzisława Jachimeckich w Zbiorach Specjalnych Biblioteki Naukowej PAU i PAN w Krakowie to korespondencja Zofii z Godzickich Jachimeckiej (1886-1973), zakupiona przez ówczesną Bibliotekę PAN w Antykwariacie Domu Książki w latach 1974-1975. Zbiór zawiera dwa listy Stryjeńskiej z Warszawy z lat 1931 i 1935³, jeden z Zakopanego z 1917 roku$^{4}$, kartkę pocztową z Fontainebleau z $1931^{5}$ oraz dwa niedatowane bileciki ${ }^{6}$.

Ponadto w Zbiorach Specjalnych Biblioteki odnajdujemy korespondencję Stryjeńskiej z roku 1931 do Kazimierza Wojciecha Witkiewicza (1880-1973), malarza, grafika, bibliotekarza Biblioteki Muzeum Przemysłowego w Krakowie ${ }^{7}$. Autorka zwraca się z prośbą do Witkiewicza o przesłanie jej wybranych przez siebie fotografii z etnograficznej wystawy zorganizowanej przez Miejskie Muzeum Przemysłowe w 1931 roku. Drugi list, z 1935 roku, adresowany jest do Mariana Krzyżanowskiego (1880-1964), księgarza, wydawcy i antykwariusza ${ }^{8}$, a wspomina w nim o materiałach na wystawę w Londynie.

W 2014 roku obszerna spuścizna rękopiśmienna Zofii Stryjeńskiej została przekazana przez rodzinę artystki Bibliotece Jagiellońskiej9. Składa się z pięćdziesięciu siedmiu jednostek, które zawierają osobiste dokumenty, m.in. odpis aktu urodzenia, kwit potwierdzający opłatę za studia w Monachium, legitymację Towarzystwa Zachęty Sztuk Pięknych w Warszawie, paszport i dyplom nagrody Fundacji Alfreda Jurzykowskiego w Nowym Jorku z 1972 roku za całokształt twórczości ${ }^{10}$. Osobny tom to głównie rachunki i korespondencja związane z pobytem Stryjeńskiej w Szwajcarii w latach 1964-1976. Materiał osobisty uzupełniają notatnik i szkicownik, życiorysy, wykazy ważniejszych prac malarskich i publikacji oraz drukowane katalogi wystaw. Następna partia to dziewiętnaście jednostek obejmujących pamiętnik Zofii Stryjeńskiej, prowadzony przez autorkę do 1956 roku $^{11}$. Są to kopie i oryginały listów, formatu A4, przepisywane przez autorkę i powklejane między osobiste wspomnienia. Całość uzupełniona jest fotografiami, dokumentami, biletami, artykułami i listami, gdyż często prosiła

3 Biblioteka Naukowa PAU i PAN (dalej: BN PAU i PAN), rkps 8006, k. 34, 37.

${ }^{4}$ Ibidem, rkps 8003, k. 104.

${ }^{5}$ Ibidem, rkps 8006, k. 33.

${ }^{6}$ Ibidem, rkps 8050, k. 61, rkps 8006, k. 36.

7 Ibidem, rkps 6942, k. 70-71.

8 Ibidem, rkps 3729, k. 75.

9 Biblioteka Jagiellońska (dalej: BJ), rkps Przyb. 108-164/15.

${ }^{10}$ M. Ja g l ar z, Spuścizna rękopiśmienna Zofii Stryjeńskiej (1891-1976) w zbiorach Biblioteki Jagiellońskiej, „Biuletyn Biblioteki Jagiellońskiej”, R. 66: 2016, s. 5-21.

${ }^{11}$ BJ, rkps Przyb.111-129/15. M. Jaglarz, Spuścizna ..., op. cit. 
adresatów o ich zwrot. Diariusz we fragmentach to 180 kartek wyrwanych z kalendarza z notatkami artystki.

Stryjeńska miała dokładną koncepcję, jak jej pamiętniki mają wyglądać w druku i na oddzielnej kartce zostawiła wskazówki. W 1995 roku za zgodą syna Zofii, Jana Stryjeńskiego, pamiętnik pt. Chleb prawie że powszedni został przygotowany do druku w dwóch tomach przez Marię Grońską. Po latach rękopis został opracowany jeszcze dwa razy: w 2015 roku przez Angelikę Kuźniak pt. Stryjeńska. Diabli nadali oraz w 2016 Chleb prawie że powszedni. Kronika jednego życia ${ }^{12}$.

Z posiadanych przez Bibliotekę PAU i PAN listów Zofii Stryjeńskiej do państwa Jachimeckich nie dowiadujemy się o szczegółach towarzyskich spotkań, ale z zaproszeń i planów możemy wnioskować, iż odwiedzano się przy często nadarzających się okazjach. Korespondencja zawiera krótkie informacje Stryjeńskiej o tym, gdzie w danym momencie jest i czym się zajmuje, nieopowiadające wiele, oszczędne w swojej treści.

Znajomość Stryjeńskiej z Jachimeckimi rozpoczęła się z chwilą ukazania się w maju 1913 roku na łamach „Czasu” artykułu Jerzego Warchałowskiego pt. Bajki w obrazach Zofii Lubańskiej. Krytyk sztuki ogłosił Lubańską nowym talentem, a jej bajki dziełem sztuki. Stała się wówczas rozpoznawalna w kręgach artystycznych i zapraszana na salony. W pamiętnikach napisała:

Znajomość z Warchałowskim, który napisał o mnie dodatnie krytyki, wciągnęła mnie w pewnym stopniu w artystyczne i towarzyskie życie Krakowa [...], zaczęto mnie zapraszać, do nas zaczęli przychodzić Żeleńscy, Puszetowie, Jachimeccy, Starzewscy... ${ }^{13}$.

Polskie bajdy na tle opowieści ludowych, które przyczyniły się do rozgłosu Stryjeńskiej, to cykl osiemnastu sztuk kartonowych obrazków z wierszowaną treścią, wypisaną ręcznie pismem naśladującym stary druk. Wystawione w 1912 roku na pierwszej indywidualnej wystawie artystki w Towarzystwie Przyjaciół Sztuk Pięknych odniosły sukces, a dzieło zakupił hrabia Edward Tyszkiewicz.

Niebawem Stryjeńska otrzymała zamówienie na malowidło ścienne o tematyce słowiańskiej w holu pierwszego piętra gmachu Muzeum Techniczno-Przemysłowego. W trakcie tej pracy zetknęła się z gronem artystów skupionych w Warsztatach Krakowskich (które miały siedzibę w Muzeum), nawiązała kontakty ze środowiskiem literackim i zawarła liczne przyjaźnie ${ }^{14}$.

Państwo Jachimeccy byli znaczącą parą pośród osób mających wpływ na życie intelektualne i kulturalne Krakowa. Zdzisław Jachimecki (1882-1953), wybitny muzykolog, dyrygent, kompozytor, profesor Wszechnicy Jagiellońskiej, członek Polskiej Akademii Umiejętności (od 1914 r. Komisji Etnograficznej, 1925 r.

${ }^{12}$ Z. Stryjeńska, Chleb...,op. cit., s. 9.

13 Ibidem, s. 25.

${ }^{14}$ J. La sk ow icka, Zofia Stryjeńska, w: Polski słownik biograficzny (dalej: PSB), t. 44, Warszawa-Kraków 2006-2007, s. 502. 
Komisji Historii Sztuki, a w 1947 r. członek zwyczajny), był także publicystą, autorem opracowań dziejów muzyki polskiej, głównie Fryderyka Chopina, Karola Szymanowskiego i Stanisława Moniuszki. Na Uniwersytecie Jagiellońskim jako pierwszy w Polsce wykładał muzykologię ${ }^{15}$.

Pisarz Jalu Kurek przedstawił Jachimeckiego następująco: „Muzykolog, profesor Wszechnicy Jagiellońskiej, miłośnik wszelkich odznaczeń i orderów, wytworny, elegancki bywalec u high-society" ${ }^{\prime \prime}$.

Profesor prowadził działalność publicystyczną, zamieszczając na łamach różnych czasopism recenzje z bieżących imprez i wydawnictw muzycznych, eseje poświęcone wybitnym muzykom oraz szkice z dziejów muzyki. Przygotowywał cykl felietonów o życiu teatralnym i muzycznym we Włoszech i Wiedniu.

Jego żona Zofia, z d. Godzicka, była tłumaczką z języka francuskiego, niemieckiego i włoskiego, zwłaszcza dramatów Luigiego Pirandella (z którym była zaprzyjaźniona), Daria Niccoleniego, Carla Goldoniego i in. Uznawana była za natchnienie dla artystów, czego dowodem są jej liczne portrety i rzeźby, m.in. dłuta Konstantego Laszczki, Ludwika Pugeta czy Xawerego Dunikowskiego (cykl Glowy wawelskie). W publicystyce kulturalnej opisywana była jako osoba, która ,pozostanie w historii obyczajowości przełomu wieków, w historii dawnego Krakowa - jako czarująca istota, muza artystów, opiewana przez poetów, uwieczniana przez malarzy"17. W 1960 r. za działalność translatorską otrzymała nagrodę PEN Clubu.

Współpracowała także z Teatrem im. Juliusza Słowackiego. Aktorzy często zwracali się do niej z prośbą o przetłumaczenie sztuk teatralnych, o dobór muzyki do przedstawień, a nawet oferowali jej role.

Z Teatrem im. Juliusza Słowackiego związana była również Zofia Stryjeńska, która projektowała tam kostiumy i scenografię do pantomimy O Maćku Piecuchu i Pannie Gapiomile Królewnie (1917) oraz przedstawień: Promienie FF Brunona Winawera (1918), Turandot Giacoma Pucciniego (1927), Balladyna (1927) i Skatka, która zainspirowała ją do stworzenia cyklu Piastowie $(1929)^{18}$. Zdzisław Jachimecki w „Głosie Narodu” napisał pochlebną opinię na temat inscenizacji O Maćku Piecuchu...:

Pani Zofia Lubańska-Stryjeńska jest autorką akcyi wysnutej z baśni ludowych i całego aparatu scenicznego, przy którego pomocy dokonano realizacji pantomimy. [...] W niebywale krótkim czasie, zaiste od ręki, powstały te barwne, dowcipne ubiory astrologa, kucharza i błazna i kraśne

15 W. Poźn ia k, Zdzisław Jachimecki, w: PSB, t. 10, Wrocław 1962, s. 266.

${ }_{16}$ J. Kurek, Błyskawiczna lista wspomnień, „Kwartalnik Historii Prasy Polskiej”, R. 19/4: 1980, s. 69.

${ }^{17}$ K. Z bij ew sk a, Ja jestem pastelowa (O Zofii Jachimeckiej), w: Z muzami pod rękę, Kraków 1991, s. 121.

${ }_{18}$ M. Chudzikowska, Talent stworzony do teatru, Zofia Stryjeńska 1891-1976: wystawa w Muzeum Narodowym w Krakowie październik 2008 - styczeń 2009, Kraków 2008, s. 40. 
stroje królewny i panien dworskich. Pomysły charakteryzacyi zdradzały silny talent karykaturzystki, rozmaitość zaś krojów i dobór barw w strojach, grających całą symfonią kolorów, dawały miarę przebogatej inwencyi malarskiej pani Stryjeńskiej ${ }^{19}$.

Wspólną pasję i wrażliwość muzyczną artystów odzwierciedla cykl Tańców polskich Stryjeńskiej z lat 1927-1929, do których Zdzisław Jachimecki opracował nuty i opatrzył najpiękniejszymi polskimi melodiami. Malarstwo artystki współgrało z muzyką, co doskonale wyraził odkrywca i wielbiciel jej talentu, wspomniany Jerzy Warchałowski:

Słucha swych impulsów malarskich z rękami na naciągniętych strunach swego instrumentu [...]. Wytęża słuch, zaostrza wzrok. Wie dobrze, że te dwa zmysły działają w sztuce społem, wzajemnie się kontrolują ${ }^{20}$.

Muzyka była dla Stryjeńskiej stałym natchnieniem. Obecna jest w ilustracjach do pastorałek, pieśni legionowych, Kujawiakach czy wybitnej kompozycji Koncert Bériota, zainspirowanej utworem XIX wiecznego kompozytora Charles'a-Auguste'a de Bériota (1802-1870). Artystka stworzyła także kostiumy do spektaklu muzycznego Kulig (1929), składającego się z piosenek i obyczajów zapustnych oraz tańców: poloneza, krakowiaka i mazura. Była autorką ilustracji do książki Stanisława Mierczyńskiego Muzyka Podhala, którą wstępem opatrzył Karol Szymanowski. Stworzyła scenografię, kostiumy oraz libretto i układ sceniczny do baletu Korowaj z muzyką Michała Kondrackiego. Po otrzymaniu propozycji pracy przy Korowaju w pamiętnikach żywiołowo wyznała:

A ja chcę brać udział w ruchu, wrzasku, kameleoństwie póz, wyrazów i we wszystkich jarmarcznych szałach życia. Niech żyje commedia dell'arte i muzyka! ${ }^{21}$

Wielki sukces odniosły jej prace przy oprawie scenicznej baletu Szymanowskiego Harnasie, których premiera odbyła się w 1938 roku w Teatrze Wielkim w Warszawie 22 .

Stryjeńska posiadała naturalną umiejętność łączenia malarstwa z muzyką i tańcem, która zachwyca po dzień dzisiejszy w ilustracjach książkowych i plastyce teatralnej. W pamiętniku z 1946 roku odnajdujemy wpis pt. Ogólne credo synestetyczne, w którym tworzy teorię syntezy sztuk, kojarząc ze sobą kolory i dźwięki.

Artystka grała także na fortepianie, co uwieczniła we wspomnieniach Magdalena Samozwaniec:

19 Z.J. [Zdzisław Jachimecki], Przedstawienie amatorskie w Teatrze miejskim im. Jul. Słowackiego, „Głos Narodu” (wydanie poranne), R. 25: 1917, nr 65, s. 2.

${ }^{20}$ J. Wa r ch ało w sk i, Zofia Stryjeńska, w: Monografje artystyczne, Kraków 1929, s. 16.

${ }^{21}$ Z. Stryjeńska, Chleb...,op. cit., s. 92.

${ }^{22}$ M. Chudzikowska, Talent..., op. cit., s. 42-43. 
[...] usłyszały na dole w saloniku głośne dźwięki fortepianu. Gdy zeszły z góry, ujrzały siedzące przy fortepianie jakieś zabawne stworzenie z murzyńską kręconą czupryną i wspaniałymi, ognistymi, ciemnymi oczami. [...] Tak sobie wejść do obcego domu i zasiąść od razu do fortepianu tego by nie zrobił byle $\mathrm{kto}^{23}$.

Teatr i muzyka były dla Stryjeńskiej i Jachimeckich wielką miłością, w której się zrealizowali. W czasie wojny Zofia Stryjeńska tworzyła projekt Witezjonu słowiańskiego teatru, w którym miały odbywać się widowiska muzyczne obrazujące wierzenia i zwyczaje Słowian. Ostatecznie opracowany w 1942 roku, nie doczekał się realizacji.

Jachimeccy przyciągali artystów, tworząc w swoim mieszkaniu przy ulicy Grodzkiej 47 w Krakowie czwartkowe spotkania artystów i ludzi nauki (zwane jour fixe). Marian Krzyżanowski wspominał:

Prof. Jachimecki ożenił się młodo i trzeba podkreślić, że wkrótce potem oboje pp. Jachimeccy zaczęli żyć i działać w Krakowie. Stworzyli piękny i estetyczny dom, który zawsze służył sztuce. Zbierali się tam najwybitniejsi ludzie, tak miejscowi, jak i z innych dzielnic kraju, a także zza granicy. Istniało nawet takie powiedzonko, że gdy kto z cudzoziemców przyjechał do Krakowa, to najpierw oglądał Bramę Floriańską, a potem spieszył do Państwa Jachimeckich ${ }^{24}$.

Jachimeccy zebrali bogaty księgozbiór, który jest unikatową i cenną kolekcją piśmiennictwa muzykologicznego, opracowań translatorskich (tylko nieliczne ukazały się drukiem), rękopisów i maszynopisów, opracowań naukowych, a także dzieł sztuki najważniejszych polskich artystów. Ideą pani Zofii po śmierci męża było przekazanie całości kolekcji Państwowemu Wydawnictwu Muzycznemu i stworzenie tam salonu-muzeum po prof. Jachimeckim. Będąc w trudnej sytuacji finansowej, udostępniła część spuścizny PWM-owi. W dwóch pokojach przy ulicy Grodzkiej zorganizowano bibliotekę im. Zdzisława Jachimeckiego. Po śmierci Zofii w 1973 roku zbiory artysty uległy rozproszeniu, m.in. znajdowały się w Instytucie Sztuki Polskiej Akademii Nauk w Warszawie, a część korespondencji trafiła na rynek antykwaryczny. I tak Biblioteka Naukowa PAN w latach 19741975 zakupiła cenny pod względem treści zespół korespondencji Zofii i Zdzisława Jacimeckich ${ }^{25}$. W zbiorze tym znalazły się listy wybitnych pisarzy, muzyków, plastyków, uczonych, a także ludzi teatru. Listy aktorów i reżyserów stanowią wartościowe źródło wiedzy na temat życia teatralnego w Polsce w okresie międzywojennym i w latach po II wojnie światowej ${ }^{26}$.

Obecnie archiwum muzykologa znajduje się w depozycie w Bibliotece Jagiellońskiej w Krakowie.

${ }^{23}$ M. S a mo zw an ie c, Maria i Magdalena, Kraków 1956, s. 110.

${ }^{24}$ M. Krzyżanow ski, Wspomnienia księgarza, w: Kopiec wspomnień, Kraków 1959, s. 143-144.

${ }^{25}$ Rkps 8000-8006, rkps 8040-8050.

${ }_{26}$ Z. Jabłońs ki, Teatralia w korespondencji Zofii i Zdzisława Jachimeckich, ,Rocznik Biblioteki Polskiej Akademii Nauk w Krakowie”, R. 21: 1976, s. [167]-168. 


\section{NOTA EDYTORSKA}

Język listów jest dosadny i bardzo współczesny. Pisownia i interpunkcja zostały nienaruszone, a dla większej przejrzystości tekstu wprowadzono w niektórych miejscach dodatkowe akapity.

Komunikaty pisane były konkretnie i wprost, co pozwala poznać autorkę jako osobę pewną siebie i zdecydowaną. Miała czytelny, pochyły charakter pisma bez „ozdobników”. Skracała wyrazy i rzadko używała znaków interpunkcyjnych. Pisała jakby pospiesznie, zazwyczaj czarnym atramentem, niekiedy na zwykłych stronach z zeszytu. Stan zachowania listów jest dobry i kompletny.

Zastanawia powtarzanie niektórych słów: „bardzo”, „serdecznie”, „mam nadzieję". Czy jest to dittografia - mimowolnie popełniony błąd, czy chęć podkreślenia znaczenia słowa?

Prawdopodobnie nie miała pamięci do liczb, gdyż często myliła w adresie państwa Jachimeckich numer kamienicy (ul. Grodzka 47 występuje w konfiguracji $\mathrm{z}$ numerami $41,43,45$, skreślanymi przez autorkę, innym razem przez urzędnika pocztowego).

1.

Korespondencja Zofii z Godzickich Jachimeckiej, rkps 8050, k. 61.

Bilecik zapisany z obu stron, niedatowany, bez koperty.

Drodzy Państwo

Mam nadzieję mam nadzieję że wreszcie uzyskam zaszczyt piątek 6-7

Dobrze?

Oczekuję z upragnieniem (café avec konieque) ${ }^{27}$. Zasyłam ukłony i serd.[eczne] pozdr.[owienia]

\section{Z. Stryjeńska}

Garnc.[arska] $7^{28}$

2.

Korespondencja Zofii z Godzickich Jachimeckiej, rkps 8003, k. 104.

List na gładkim papierze, zapisany z jednej strony czarnym atramentem. Zachowana koperta z czerwonym, austriackim znaczkiem, zaadresowana do Zofii Jachimeckiej słowami: Wielmożna Pani Zdzisława Jachimecka.

27 Właśc. café avec cognac (fr.) - kawa z koniakiem.

${ }^{28}$ Przy ulicy Garncarskiej 7 mieściło się mieszkanie rodziny Lubańskich. Było obszerne, parterowe, posiadało ogród. Państwo Lubańscy w latach 1901-1910 przeprowadzali się co najmniej kilkanaście razy. W 1916 r. po zaślubinach Zofii z Karolem Stryjeńskim na ulicy Garncarskiej odbyło się kameralne przyjęcie. 


\section{Droga Pani}

Spóźnione z powodu mego wyjazdu ale proszę przyjąć szczere życzenia wszystkiego najlepszego w dniu imienin. Zasyłam Państwu też pozdrowienia z Zakopanego gdzie kąpię się przyjemnie w nudzie ${ }^{29}$.

\section{Z. Stryjeńska}

\section{Zakopane 16.V.1917}

3.

Korespondencja Zofii z Godzickich Jachimeckiej, rkps 8006, k. 33.

Kartka pocztowa ze zdjęciem Palais de Fontaineblau, Salon Français $1^{\circ}$. Błąd w nr. domu: 41 zamiast 47.

Najserdeczniejsze pozdrowienia i piękne ukłony zasyła Drogim Miłym Państwu z Fontenebleau ${ }^{30}$ które zwiedzam w powrotnej drodze ze Szwajcaryi ${ }^{31}$. W Paryżu

${ }^{29}$ Pensjonat „Szałas” w Zakopanem przy ulicy Kasprusie 14c znajdował się w zabytkowej willi, wybudowanej w 1898 r. Do 1904 r. prowadzony był przez Emilię Brzozowską, a później przez jej syna Kazimierza z żoną Urszulą. Była to rodzina Kazimierza Brzozowskiego, malarza i grafika, współzałożyciela Stowarzyszenia Kilim. Gospodarze urządzali wieczory muzyczne, a pani Brzozowska, która pochodziła z Kujaw, zapoznawała towarzystwo z muzyką kujawską (M. P in k w art, Zakopiański Broadway - Ścieżki czasu. Ulica Kasprusie (cz.1), „Dziennik Polski” z 7.08.2009, s. [1]).

To do tego pensjonatu 4 listopada 1916 r. Zofia i Karol Stryjeńscy przyjechali w podróży poślubnej: „Przyjeżdżamy do Zakopanego, cudna zima, słońce, śniegi po pas - stajemy w pensjonacie Szałas. Gospodarze, sympatyczni państwo Brzozowscy, urządzają wieczory muzyczne, na których Egon Petri gra klasyków. Pewnego razu p. Urcia Brzozowska przegrywa kujawiaki ze swoich okolic, z Kujaw, teksty i melodie wywierają na mnie silne wrażenie. Szkicuję pomysły do ilustracji do tych melodii, ukrywając się w odległej chacie góralskiej, aby mi nie przeszkadzano. Za powrotem udaję, że byłam na nartach, i przecierzgam się na nowo w kokieteryjną młodą małżonkę" (Z. S try jeńska, Chleb..., op. cit., s. 26-27). Po powrocie do Krakowa, gdzie mieszkała z mężem na Salwatorze, powstają pierwsze próby dzieła.

Bogate życie towarzyskie męczyło Stryjeńską, nic nie mówiąc mężowi, powróciła więc na dwa tygodnie do „Szałasu” w celu tworzenia w samotności Kujawiaków. Praca nie została dokończona, a cykl niewydany, ale kompozycje, składające się z 24 pięciobarwnych plansz o rozmiarach $60 \times 76 \mathrm{~cm}$, brały udział w wielu wystawach, a poszczególne były reprodukowane. Obecnie w willi „Szałas” znajduje się Zespół Szkół Zawodowych im. Aleksandra Dziedzica, wcześniej była tam siedziba Technikum Tkactwa Artystycznego im. Heleny Modrzejewskiej.

${ }^{30}$ Właśc. Fontainebleau (fr.).

${ }^{31}$ Na przełomie kwietnia i maja 1931 r. Stryjeńska przebywała we Francji i Szwajcarii wraz ze swoim drugim mężem Arturem Klemensem Sochą (1896-1943), aktorem filmowym i teatralnym. Spędzała czas w willi Ignacego Paderewskiego. Tak opisała wrażenia z tej podróży: „Jakem do Paderewskich pojechała do Morges, natrafiłam w Riond-Bosson na lokaja Francuza, który mnie nawet do ogrodu nie dopuścił. Na trawie w lesie leżałam i przez gałęzie krzaków spoglądałam, jak Paderewski z sekretarzem Strakaczem odjeżdżają do Gugaudine i jak tenże lokaj zatrzaskuje drzwi samochodu, ale ciężar taki przytłaczał mą duszę, że nie chciało mi się dźwignąć i przeleżałam tak 
Wystawa kolonialna troszkę mię zawiodła gdyż z powodu deszczów i zimna najwspanialsi dzicy pouciekali do swych krajów ${ }^{32}$. No ale zawsze w Paryżu jest co oglądać. Będzie mi niezmiernie miło ujrzeć Szanownych Państwa w Krak.[owie] dokąd wybieram się we wrześniu i biorę na żywiołową wymianę wrażeń.

Paryż, 30.VIII.1931

Z. Stryjeńska

4.

Korespondencja Zofii z Godzickich Jachimeckiej, rkps 8006, k. 36.

Bilecik niedatowany bez koperty, zapisany z obu stron.

\section{Szanowni Państwo}

Dziękuję bardzo bardzo za xiążkę i za pamięć (!).

Zasyłam ukłony i czekam na sposobność osobistego wysławienia swej wdzięczności.

\section{Zofia Stryjeńska}

\section{5.}

Korespondencja Zofii z Godzickich Jachimeckiej, rkps 8006, k. 34.

List małego formatu na błękitnej papeterii z kopertą, Warszawa 22.XII.193133 - data ze stempla pocztowego. Zapisany z jednej strony. Na kopercie poprawiony nr domu z 43 na 47 z dwoma znaczkami, zaadresowany do Zofii Jachimeckiej.

Serdeczne Serdeczne życzenia Wesołych Świąt i szczęśliwego Nowego Roku przesyła Drogim i Kochanym Państwu załączając piękne ukłony Zofia Stryjeńska.

do popołudnia, słuchając ćwierkania ptactwa leśnego, i wróciłam do Warszawy" (Chleb..., op. cit., s. 394). W sierpniu zwiedziła Wystawę Kolonialną w Paryżu, wkrótce wyjechała do Fontainebleau, skąd we wrześniu wróciła do Krakowa.

${ }^{32}$ Międzynarodowa Wystawa Kolonialna w Paryżu została otwarta 6 maja 1931 r. przez prezydenta Francji Gastona Doumergue'a. Tereny wystawowe rozciągały się w Parc de Vincennes, którego część na tę okoliczność została przebudowana na ogród zoologiczny. Wzniesiono gmach Muzeum Kolonialnego, gdzie eksponowano wiele odtworzonych budowli egzotycznych kultur z Tunisu, Algieru, Maroka i innych kolonii. Specjalną atrakcję stanowiły wspaniałe fontanny i efekty oświetleniowe (por. Przewodnik po wystawie Międzynarodowej Kolonjalnej w Paryżu, Paryż 1931). Ze względu na XVIII-wiecznych kolonizatorów, Maurycego Beniowskiego i Tomasza Stanisława Wolskiego, Polska została zaproszona do współudziału w imprezie, ale nie skorzystała z zaproszenia (O udziat Polaków w Międzynarodowej Wystawie Kolonialnej w Paryżu, ,, Kurier Poznański" 1930, nr 466, s. [1]).

${ }^{33}$ W listopadzie 1931 r. projekty teatralne Stryjeńskiej zostały pokazane podczas Salonu Jesiennego w Grand Palais des Champs Élysées w Paryżu na Międzynarodowej Wystawie Teatralnej. Były to dwie prace inspirowane Skatka S.Wyspiańskiego i Marchołtem J. Kasprowicza. Pokazano wówczas dzieła 27 polskich artystów z lat 1900-1931 (M. Chudzikowska, Talent..., op. cit., s. 44). 
6.

Korespondencja Zofii z Godzickich Jachimeckiej, rkps 8006, k. 37.

List napisany niebieskim atramentem, równym, starannym pismem. Gładki, zwykły papier z kopertą, na której przekreślony nr domu z 45 na 47, zaadresowany słowami: Dr Zdzisławowie Jachimeccy. Na kopercie widnieje pieczęć propagująca ekologię z napisem Święto Lasu. Poznaj swoje lasy.

\section{Wielce Szanowni Państwo!}

Najuprzejmiej dziękuję za chęć dopomożenia mi w sprawie Wystawy w Tow. [arzystwie] Sztuk P.[ięknych] podczas „Dni Krakowa”34. Później jednakże doszłam do przekonania że charakter turystyczny oraz cały nastrój publiczności jaki będzie przepływać przez sale T. Szt. P. będzie kolidować troszkę z nowemi memi pracami wobec tego zatrzymam się z wystawą do jesieni lub nawet zimy ${ }^{35}$. $\mathrm{Z}$ pewnych powodów musiałam powrócić do Warszawy wcześniej niż to było mym zamiarem i stąd raz jeszcze serdecznie dziękuję i łączę najpiękniejsze ukłony i pozdrowienia.

\section{Zofia Stryjeńska}

\section{Warszawa 27.IV.1935}

${ }^{34}$ Dni Krakowa, zainicjowane w 1934 r. przez Jerzego Dobrzyckiego, po raz pierwszy zorganizowane przez Zarząd Miasta i Polski Związek Turystyczny 9-24 VI 1936 r., miały odbywać się cyklicznie co dwa lata (por. „Kraków.pl. Dwutygodnik miejski” 2014, nr 10(137)).

Wystawa, z której Stryjeńska zrezygnowała, to Kraków i Ziemia Krakowska w sztuce, odbywająca się w Pałacu Sztuki przy pl. Szczepańskim. Przygotowując się do wystawy w Instytucie Propagandy Sztuki (IPS) w Warszawie, artystka wycofała się z uczestnictwa w Dniach Krakowa, te jednak zostały odwołane ze względu na żałobę po śmierci Józefa Piłsudskiego.

${ }^{35} 23$ V 1935 r. Stryjeńska wraz z Rafałem Malczewskim otwarła wystawę w IPS-ie. Artystka eksponowała 108 prac, m.in. Bogowie stowiańscy (IV), szkice kostiumów do baletu Karola Szymanowskiego Harnasie, projekt do widowiska Korowaj i misterium Pascha. Pieśń wielkanocna (według własnego scenariusza). W tym okresie borykała się z problemami finansowymi i tęsknotą za dziećmi, które mieszkały w Krakowie. Prawdopodobnie do końca 1935 roku nie dotarła do Krakowa, a wystawę w IPS-ie zajął komornik. Wiktor Podoski pisał: „Na obecnej wystawie oglądamy szereg obrazów temperą, nowy cykl Bogów Słowiańskich (kreda kolorowa) i szkice akwarelowe kostjumów, do baletów Harnasie i Korowaj. Zwłaszcza w Bogach błysnął znowu lwi pazur artystki. Te rysunki kredą kolorową, nadzwyczaj jędrne i zwarte, pomysłowe i wyraziste, często odnaturalizowane do ostatka, zostały wykonane najwidoczniej sobie a muzom na uciechę. Jest tu kawał serca, a w rozmaitych zalecankach temperowych, które w końcu znajdą się u jakiegoś Kunsthändlera, nie zawsze można je odszukać” (W. Pod oski, Z plastyki. Stryjeńska i Malczewski w IPS-ie, „ABC: nowiny codzienne", R. 10: 1935, nr 149). W 1946 roku Stryjeńska próbowała sprzedać cykl Bogów słowiańskich, jednak bezskutecznie: „Szkoda, że nie mam jakich obrazów sprzedażnych, tylko Bogów słowiańskich. Spróbowałam pokazać to kilku marszandom obrazów, ale nie dało się sprzedać. Powiedzieli, że ich interesuje tylko sztuka francuska. Jakbym wymalowała kilka nagich dziwek, może by poszło, ale nie wiem, co mi się stało, że na widok farb i pędzli dostaję takiej odrazy, że pianę toczę" (Chleb..., op. cit., s. 395). 
IWONA BRANC

\author{
LETTERS BY ZOFIA STRYJEŃSKA (1891-1976) \\ TO ZOFIA AND ZDZISŁAW JACHIMECKI \\ IN THE COLLECTION OF THE LIBRARY OF THE PAAS AND THE PAS \\ IN CRACOW
}

Keywords: Zofia Stryjeńska, Zofia Jachimecka, Zdzisław Jachimecki, musicology in $\mathrm{XX}$ c., painting in XX c., polish theatre in XX c., correspondence XX c., Cracow (Poland) - intellectual life in XX c.

\title{
Summary
}

The edition of letters written by Zofia Stryjeńska (1891-1976), an outstanding artist of the interwar period, to Zofia and Zdzisław Jachimecki includes several letters from the years 1917, 1931 and 1935. Zofia Jachimecka (1886-1973), a translator from Italian and German and her husband Zdzisław (1882-1953), a musicologist, ran an artistic \& social salon in their apartment at ul. Grodzka 47 in Cracow.

Kept in the Special Collection of the Scientific Library of the PAAS and the PAS, the short and concise correspondence recalls the times of the cultural elite of the interwar period.

The paper presents the life and artistic achievements of Stryjeńska and Zofia and Zdzisław Jachimecki. Their mutual interest in music and theatre and a similar way of perceiving art are visible in their artistic output.

The paper contains many quotations from persons connected with intellectual Cracow, which testifies to the significant status of Stryjeńska and Jachimecki. The content of letters created an opportunity to recall the names of outstanding persons who have been connected with the culture and science of Cracow.

\section{ИВОНА БРАНЦ (IWONA BRANC)}

ПИСЬМА ЗОФИИ СТРЫЕНСКОЙ (1891-1976), НАПИСАННЫЕ ЗОФИИ И ЗДЗИСЛАВУ ЯХИМЕЦКИМ

В ФОНДАХ НАУЧНОЙ БИБЛИОТЕКИ ПОЛЬСКОЙ АКАДЕМИИ ЗНАНИЙ (РАU) И ПОЛЬСКОЙ АКАДЕМИИ НАУК (РАN) В КРАКОВЕ

Ключевые слова: София Стрыеньская, София Яхимецкая, Здзислав Яхимецкий, музыковедение XX в., живопись XX в., польский театр XX в., переписка XX в., Краков (Польша) - интеллектуальная жизнь XX в.

\section{Резюме}

Издание писем Зофии Стрыенской (1891-1976), выдающейся артистки межвоенного двадцатилетия, которые она писала Зофии и Здзиславу Яхимецким - это несколько писем с 1917, 1931 и 1935 годов. Зофия Яхимецка (1886-1973), переводчица итальянского и немецкого языков, а также ее муж Здзислав (1882-1953), музыковед, вели в своей квартире по ул. Гродзкой 47 в Кракове светский художественный салон. 
Короткая, скупая в слова переписка, находящаяся в Специальных фондах Научной библиотеки Польской академии знаний (PAU) и Польской академии наук (PAN), напоминает о временах культурной элиты межвоенного периода.

В статье представлена жизнь и творческие свершения Стрыенской, а также Зофии и Здислава Яхимецких. Общая любовь к музыке и театру, а также похожий способ восприятия искусства, заметны в их художественных достижениях.

Многочисленные цитаты людей, связанных с интеллектуальным Краковом, собранные в этой статье, свидетельствуют о значительном ранге Стрыенской и Яхимецких. Содержание писем позволило вспомнить фамилии выдающихся людей, которые до нынешних дней связаны с культурой и наукой Кракова. 